Psihologijske teme, 27 (2018), 3, 409-435

Izvorni znanstveni rad - UDK - 613.88-053.6

159.922.8.072

doi:https://doi.org/10.31820/pt.27.3.4

\title{
Uloga dispozicijskih, socijalizacijskih i ponašajnih čimbenika u dinamici slanja seksualno eksplicitnih poruka u adolescenciji
}

\author{
Jakov Burić \\ Opća županijska bolnica Požega, Hrvatska \\ Jasminka Juretić \\ Sveučilište u Rijeci, Filozofski fakultet, Odsjek za psihologiju, Hrvatska
}

Aleksandar Štulhofer

Sveučilište u Zagrebu, Filozofski fakultet u Zagrebu, Odsjek za sociologiju, Hrvatska

\begin{abstract}
Sažetak
Istraživanja sugeriraju kako se značajan broj mladih koristi seksualno eksplicitnim materijalom (SEM). Istodobno, razvoj je mobilnih tehnologija i internetskih društvenih mreža omogućio novo seksualizirano ponašanje - slanje seksualiziranih poruka (engl. sexting). Dosadašnja su istraživanja povezala uporabu SEM-a, odnosno slanja seksualno eksplicitnih poruka, s rizičnim spolnim ponašanjima i nekim drugim neželjenim ishodima. Vodeći se modelom diferencijalne osjetljivosti na efekte medija (DSMM; Peter i Valkenburg, 2013), cilj je ovoga longitudinalnog istraživanja bio ispitati doprinos stupnja obrazovanja roditelja, roditeljske kontrole, samopoštovanja, traženja uzbuđenja, anksioznosti i depresivnosti, religioznosti, seksualne inicijacije, korištenja internetskih društvenih mreža te korištenja SEM-a u predikciji slanja seksualno eksplicitnih poruka. Istraživanje je provedeno na populacijskom uzorku koji je uključio 791 riječkog srednjoškolca (302 mladića i 489 djevojaka) prosječne dobi od 15.8 godina $(S D=0.51)$. Podaci su prikupljeni u dvije vremenske točke u razmaku od 12 mjeseci. Od ukupnog broja sudionika $46 \%$ je mladića u prvom i $37.7 \%$ u drugom mjerenju bar jednom poslalo seksualiziranu poruku, dok je isto ponašanje označilo 36.6.\% djevojaka u prvom i $33.7 \%$ u drugom mjerenju. S obzirom na to da je seksualna socijalizacija adolescenta idalje velikim dijelom spolno specifična, analize su provedene odvojeno po spolu. Rezultati multivarijatne analize (korištena je hijerarhijska logistička regresija s kontrolom inicijalne razine ishoda) pokazali su kako djevojke koje su u prvom mjerenju sklonije traženju uzbuđenja, djevojke koje su stupile u spolni odnos te one koje se koriste SEM-om češće šalju seksualno eksplicitne poruke u drugoj točki mjerenja. U poduzorku se mladića samo traženje uzbuđenja pokazalo značajnim pozitivnim prediktorom ishoda. Imajući u vidu golemu popularnost internetskih društvenih mreža među mladima, dobiveni nalazi upućuju na važnost sustavnog promicanja medijske pismenosti te boljeg razumijevanja motivacije za slanje seksualiziranih poruka, kao i potencijalnih rizika, $\mathrm{u}$ adolescenciji.
\end{abstract}

Ključne riječi: seksualno eksplicitni materijal, seksualizirane poruke, traženje uzbuđenja, seksualna inicijacija, adolescenti

Jakov Burić, Opća županijska bolnica Požega, Osječka 107, 34000 Požega, Hrvatska. Epošta: jakov.buric22@gmail.com 


\section{Uvod}

Zahvaljujući tehnološkom napretku mobilni uređaji omogućavaju mladima brzo povezivanje putem širokog spektra društvenih i vizualnih medija. Uz percipirane koristi novih medija u javnosti se često javlja zabrinutost oko mogućih negativnih posljedica vezanih uz novonastale metode održavanja socijalnih odnosa. Jedna se od takvih metoda odnosi na slanje seksualiziranih poruka (engl. sexting), koje se definira kao slanje seksualnih poruka, vlastitih slika i/ili videa nekoj osobi internetom (Klettke, Hallford i Mellor, 2014). Prevalencija slanja seksualiziranih poruka kod američkih adolescenata kreće se od 10\% do 35\% (Klettke i sur., 2014), a povećava se s dobi (Mitchell, Finkerhor, Jones i Wolak, 2012). Istraživanje provedeno na uzorku od 18709 europskih adolescenata navodi prosječnu prevalenciju od 3.4\% (Baumgartner, Sumter, Peter, Valkenburg i Livingstone, 2014), dok istraživanje provedeno na 1028 belgijskih adolescenata navodi kako je $11.1 \%$ sudionika slalo seksualizirane poruke (Van Ouytsel, Van Gool i Ponnet, 2014). U Hrvatskoj je do sada provedeno jedno istraživanje na uzorku od 311 adolescenata, u kojem je njih 39.9\% barem jednom u životu poslalo seksualiziranu poruku (Vrselja, Pacadi i Maričić, 2015). Kod ispitivanja spolnih razlika rezultati nisu jednoznačni. Neka istraživanja navode kako djevojke češće šalju seksualizirane poruke (Mitchell i sur., 2012), dok druga navode kako nema razlika između mladića i djevojaka (Benotsch, Snipes, Martin i Bull, 2013; Lenhart, 2009).

Istraživanja upućuju na nekoliko mogućih motiva za slanje seksualiziranih poruka, poput načina flertovanja, održavanja intimnosti u partnerskom odnosu, vrste eksperimentiranja, ali i pritiska od strane partnera (Cooper, Quayle, Jonsson i Svedin, 2016). Ipak, slanje se seksualiziranih poruka najčešće odvija unutar romantične veze (Klettke i sur., 2014), a često se i preporuča od strane partnerskih terapeuta parovima s ciljem poboljšanja seksualne komunikacije i zadovoljstva odnosom (Leshnoff, 2009).

Pregledom se literature mogu uočiti dva pristupa ispitivanju ovog fenomena. Nešto učestaliji pristup opisuje praksu slanja seksualiziranih poruka kao rizično i devijantno ponašanje naglašavajući potrebu za intervencijom i prevencijom (Kosenko, Luurs i Binder, 2017), dok drugi pristup ovu praksu opisuje kao normalan, zdravi oblik seksualnog izražavanja i interpersonalnih odnosa (Doring, 2014). Spominjani se rizici često odnose na mogućnost otkrivanja sadržaja seksualiziranih poruka osobama kojima poruke nisu bile namijenjene (Leshnoff, 2009), što u nekim slučajevima može rezultirati uznemiravanjem internetom (engl. cyberbullying). Prosljeđivanje takvih poruka može imati ozbiljne posljedice za vlasnika zbog mogućnosti vršnjačkog zlostavljanja. Kada su u pitanju adolescenti, stvaranje i širenje seksualiziranih poruka može se smatrati i vrstom dječje pornografije (Ostrager, 2010), a otkrivene osobe mogu podleći ozbiljnim zakonskim kaznama. Iako su ovo mogući ishodi, istraživanja ipak pokazuju kako većina osoba nikada nije 
imala negativno iskustvo sa slanjem seksualiziranih poruka (Dir i Cyders, 2014; The National Campaign, 2008).

Osim navedenih negativnih posljedica u većem je broju istraživanja ispitivana povezanosti slanja seksualiziranih poruka $\mathrm{s}$ različitim rizičnim seksualnim ponašanjima. Usmjerenost na ovu tematiku vjerojatno kreće od američkoga nacionalnog istraživanja provedenog na 1280 adolescenata koje je pokazalo da $38 \%$ mladih smatra kako slanje seksualiziranih poruka povećava vjerojatnost pronalaska partnera s kojim bi mogli stupiti u spolni odnos (The National Campaign, 2008). Rezultati su daljnjih istraživanja uglavnom izvještavali o povezanosti slanja seksualiziranih poruka s ranijim stupanjem u spolne odnose (Temple i sur., 2012) te upuštanjem u visoko rizična spolna ponašanja, poput učestalog mijenjanja spolnih partnera i nekorištenja zaštite tijekom spolnog odnosa (Benotsch i sur., 2013; Crimmins i Seigfried-Spellar, 2014; Rice i sur., 2012). Benotsch i suradnici (2013) zaključuju kako slanje seksualiziranih poruka sa sobom donosi nove seksualne rizike. Iako navedena transverzalna istraživanja pronalaze povezanost između slanja seksualiziranih poruka i različitih oblika rizičnih seksualnih ponašanja, zanimljivo je longitudinalno istraživanje provedeno na 964 adolescenta (Temple i Choi, 2014). Autori su proveli dva mjerenja u razmaku od 12 mjeseci kako bi ispitali hoće li oni mladi koji inicijalno šalju seksualizirane poruke biti skloniji stupanju u spolni odnos i upuštanju u rizična spolna ponašanja (nekorištenje zaštite, veći broj spolnih partnera i korištenje alkohola i/ili droga prije spolnog odnosa). Rezultati su pokazali kako je slanje seksualiziranih poruka u prvom mjerenju značajno predviđalo stupanje $\mathrm{u}$ spolni odnos 12 mjeseci kasnije, ali ne i upuštanje u spolno rizična ponašanja.

Nedavno je provedena metaanaliza s ciljem sažimanja različitih rezultata istraživanja o povezanosti slanja seksualiziranih poruka i seksualnog ponašanja (Kosenko i sur., 2017). Metaanalizom je obuhvaćeno 15 radova s ukupno 18190 sudionika. Rezultati su pokazali kako postoji pozitivna povezanost slanja seksualiziranih poruka i upuštanja u seksualne aktivnosti, nekorištenja zaštite te broja spolnih partnera. Sami autori naglašavaju kako rezultati njihove analize upućuju na to da se slanje seksualiziranih poruka i seksualna ponašanja pojavljuju zajedno, ali transverzalna priroda većine istraživanja onemogućuju uzročno zaključivanje. Slanje seksualiziranih poruka može djelovati kao uvod u spolnu aktivnost, ali i samo slanje poruka može biti dio ponašanja spolno aktivne osobe. Rezultati ove metaanalize djelomično idu u prilog teoriji problematičnog ponašanja (Jessor i Jessor, 1977), prema kojoj različita problematična ponašanja proizlaze iz istih uzroka, a pojedinci koji se upuštaju u jednu vrstu problematičnog ponašanja će se vjerojatno upuštati i u druga problematična ponašanja.

Uzimajući u obzir povezanost slanja seksualiziranih poruka i sklonosti ka rizičnim spolnim ponašanjima neki autori smatraju kako se u podlozi nalazi traženje uzbuđenja. Traženje uzbuđenja je crta ličnosti koja motivira osobu ka traženju novosti i intenzivnih iskustava (Zuckerman, 1979). Osobe sklonije traženju uzbuđenja često poduzimaju brojne rizike kako bi doživjeli uzbuđujuće i intenzivno 
iskustvo. Rezultati dosadašnjih istraživanja uglavnom upućuju na povezanost traženja uzbuđenja sa slanjem seksualiziranih poruka (Dir, Cyders i Coskunpinar, 2013), upuštanjem u rizična spolna ponašanja (Hoyle, Fejfar i Miller, 2000; Zuckerman, 1994) i konzumiranjem alkohola (Cyders, Flory, Rainer i Smith, 2009). Neka istraživanja, međutim, ne navode povezanost traženja uzbuđenja i slanja seksualiziranih poruka kod odraslih (Delevi i Weisskirch, 2013). Moguće je da kada su u pitanju odrasli, takvo ponašanje više ne predstavlja novost i ne doživljava se rizičnim, nego uobičajenom metodom komunikacije među partnerima. Adolescenti, međutim, tek otkrivaju vlastitu seksualnost, pa im slanje seksualiziranih poruka može predstavljati nešto uzbudljivo i zabranjeno. S obzirom na to da će većina osoba koja se upušta u visoko uzbudljive i rizične aktivnosti ipak pokušati umanjiti negativne posljedice poduzimajući različite mjere opreza (Zuckerman, 1991), moguće je da slanje seksualiziranih poruka upravo djeluje kao blaža opcija izlaganju seksualnim rizicima.

Istraživanja su se bavila ispitivanjem i drugih korelata upuštanja u rizična ponašanja, poput samopoštovanja, religioznosti, anksioznosti i depresivnosti te roditeljske kontrole. Primjerice, Dake, Price, Mazriaz i Ward (2012) navode da je slanje seksualiziranih poruka povezano s osjećajem depresivnosti. Istraživanje provedeno na uzorku od 1028 belgijskih adolescenata također pronalazi povezanost osjećaja depresivnosti i slanja seksualiziranih poruka (Van Ouytsel i sur., 2014) što je, međutim, u suprotnosti s istraživanjem Temple i sur. (2014) u kojem povezanost nije dobivena. Rezultati istraživanja na uzorku hrvatskih adolescenata sugeriraju da depresivnost, anksioznost i ljutnja nisu značajni prediktori u slanju seksualiziranih poruka (Vrselja i sur., 2015).

Samopoštovanje je često istraživano kao mogući zaštitni čimbenik u kontekstu rizičnih ponašanja, a podrazumijeva pozitivne ili negativne stavove koje imamo prema sebi (Rosenberg, 1965). Istraživanja, načelno, povezuju nisko samopoštovanje sa zdravstveno ugrožavajućim ponašanjima, poput konzumiranja droga i rizičnih spolnih ponašanja (Lejuez, Simmons, Aklin, Daughters i Dvir, 2004; Magnani, Seiber, Gutierrex i Vereau, 2001). U skladu s tim, istraživači su ispitivali povezanosti samopoštovanja i slanja seksualiziranih poruka, ali rezultati nisu uvijek bili jednoznačni. Scholes-Balog, Francke i Hemphill (2016) navode kako je visoko samopoštovanje zaštitni čimbenik samo kod slanja eksplicitnih slika ili videa, ali ne i kod slanja seksualno sugestivnih slika i poruka. Drugi autori ne navode povezanost samopoštovanja i slanja seksualiziranih poruka (Gordon-Messer, Bauermeister, Grodzinski i Zimmerman, 2013; Hudson i Fetro, 2015; Vanden Abeele, Campbell, Eggermont i Roe, 2014). Hudson i Fetro (2015) kao moguće objašnjenje nepostojanja te povezanosti vide u pretpostavci da osobe niskog i visokog samopoštovanja podjednako učestalo šalju seksualizirane poruke, ali iz različitih razloga. Osobe višeg samopoštovanja mogu poslati takvu poruku kao vrstu poklona partneru, dok osobe nižeg samopoštovanja to mogu raditi zbog pritiska od strane partnera. 
Polazeći od istraživanja koja upućuju na negativnu povezanost religioznosti s rizičnim seksualnim ponašanjem (Simons, Burti i Peterson, 2009), neki su autori istraživali odnos religioznosti i slanja seksualiziranih poruka. Tako Strassberg, Rullo i Mackaronis (2014) navode negativnu povezanost, ali naglašavaju kako određeni učinak postoji, ponajviše zbog vrlo religioznih pojedinaca koji izvještavaju o nižoj učestalosti slanja seksualiziranih poruka. S druge strane, Perkins, Becker, Tehee i Mackelprang (2014) ne pronalaze povezanost religioznosti i slanja seksualiziranih poruka. Osim religioznosti, neki autori navode roditeljsku kontrolu kao mogući zaštitni čimbenik kod rizičnih seksualnih ponašanja. Roditeljska se kontrola definira kao upućenost roditelja u ono što njihova djeca čine i s kim provode svoje slobodno vrijeme (Wang, Stanton, Deveaux i Lunn, 2015). Rezultati istraživanja sugeriraju da su mladi koji imaju viši stupanj roditeljske kontrole manje seksualno iskusni u odnosu na vršnjake (Wight, Williamson i Henderson, 2006), no rijetka su istraživanja koja su se bavila ispitivanjem odnosa roditeljske kontrole i slanja seksualiziranih poruka. Ipak, nedavno provedeno transverzalno istraživanje na hrvatskom uzorku adolescenata pokazalo je kako je roditeljska kontrola negativno povezana $\mathrm{s}$ učestalošću slanja seksualiziranih poruka (Tomić, Burić i Štulhofer, 2018). Nešto su brojnija istraživanja koja su se bavila ispitivanjem roditeljskog nadgledanja korištenja mobilnih uređaja, a rezultati su pokazali kako takvo ponašanje nije bilo povezano s učestalošću slanja seksualiziranih poruka (Campbell i Park, 2014; Martinez-Prather i Vandiver, 2014).

Promatra li se slanje seksualiziranih poruka kao moguće rizično ponašanje, može se očekivati kako će ono biti povezano i s nekim drugim rizičnim seksualiziranim ponašanjima, poput korištenja seksualno eksplicitnog materijala (SEM), međutim, takva su istraživanja rijetka. Prema istraživanju provedenom na uzorku od 1265 adolescenata u Hrvatskoj SEM se pokazao kao pozitivan prediktor slanja seksualiziranih poruka (Tomić i sur., 2018). Čini se da korištenje seksualiziranih medija povećava motivaciju za slanjem seksualiziranih poruka (Van Ouytsel, Ponnet i Walrave, 2014). S obzirom na postojanje povezanosti korištenja jedne vrste seksualiziranih medija s drugom vrstom takvih medija, postavlja se pitanje hoće li korištenje primarno neseksualiziranih medija, poput društvenih mreža, biti povezano sa slanjem seksualiziranih poruka. Naime, seksualizirane se poruke mogu slati, osim preko mobilnih uređaja, i preko različitih društvenih mreža. Do sada, međutim, nije provedeno nijedno istraživanje koje je ispitivalo odnos korištenja društvenih mreža i slanja seksualiziranih poruka.

Pregledom se postojećih istraživanja na ovu temu može uočiti kako je većina eksploratorna. Upravo je zbog toga nedavno predložen model čiji je cilj sintetizirati različite teorije u jedinstveni okvir koji može služiti istraživačima koji se bave ispitivanjem učinaka medija. Radi se o modelu diferencijalne osjetljivosti na učinke medija (engl. Differential Susceptiblity to Media effects Model; DSMM; Valkenburg i Peter, 2013). DSMM se sastoji od četiri dijela koja navode moguće odnose između različitih varijabli i pruža istraživačima smjernice o tome koje varijable mogu biti 
relevantne kod ispitivanja povezanosti korištenja različitih medija i ponašanja. $U$ kontekstu je teme ovoga rada važan prvi dio modela, prema kojem učinci medija ovise o tri vrste diferencijalno-osjetljivih varijabli: dispozicijskoj, razvojnoj i socijalnoj osjetljivosti. Dispozicijska se osjetljivost odnosi na dimenzije koje predisponiraju osobu k određenom odabiru i reagiranju na medije, poput crta ličnosti, motivacija, raspoloženja i sl. Neke su od navedenih dimenzija relativno stabilne kroz vrijeme (npr. ličnost, temperament), dok su druge osjetljivije na promjene (npr. raspoloženja, motivacija) (Gray i Watson, 2001). Razvojna se osjetljivost odnosi na selektivnost upotrebe i reaktivnost na medije s obzirom na kognitivni, socijalni i emocionalni razvoj. Efekti medija su najizraženiji upravo u razdoblju adolescencije, koja je karakterizirana ubrzanim razvojem i formiranjem ličnosti i stavova. Socijalna se osjetljivost odnosi na sve socijalno-kontekstualne čimbenike koji mogu utjecati na nečiji odabir i reaktivnost na medije, poput obitelji, prijatelja, škole i sl. Osobe imaju sklonost traženju one vrste medija koja djelomično odgovara njihovim predispozicijama (Klapper, 1960), društvenim normama (McDonald, 2009) i razvojnoj razini (Valkenburg i Cantor, 2000).

Vodeći se DSMM-om, može se, primjerice, očekivati kako će mladi skloniji traženju uzbuđenja češće koristiti SEM, ali i slati seksualizirane poruke, s obzirom na to da se radi o seksualiziranim ponašanjima koja su međusobno povezana (Tomić i sur., 2018). Moguće je analizirati one varijable koje se u istraživanjima opisuju kao zaštitne (npr. samopoštovanje) te one koje su rizični čimbenici (npr. traženje uzbuđenja).

Cilj je ovog istraživanja ispitati doprinose varijabli koje se odnose na dispozicijsku osjetljivost (traženje uzbuđenja, samopoštovanje, religioznost te anksioznost i depresivnost), varijabli koje se odnose na socijalnu osjetljivost (tip škole, obrazovanje majke i oca te roditeljska kontrola) te doprinose ponašajnih varijabli (seksualna inicijacija, korištenje internetskih društvenih mreža te uporaba SEM-a) u objašnjenju slanja seksualiziranih poruka kod adolescenata. Uzimajući u obzir rezultate dosadašnjih istraživanja, očekuje se da će roditeljska kontrola, samopoštovanje i religioznost biti negativno povezani $\mathrm{s}$ praksom slanja seksualiziranih poruka, dok će traženje uzbuđenja, anksioznost i depresivnost, seksualna inicijacija, korištenje internetskih društvenih mreža i SEM-a biti pozitivno povezano sa slanjem seksualiziranih poruka. U skladu je s DSMM-om pretpostavka da će varijable koje se odnose na dispozicijsku osjetljivost (traženje uzbuđenja, samopoštovanje i religioznost) imati značajan učinak $u$ predviđanju slanja seksualiziranih poruka tako što će adolescenti skloniji traženju uzbuđenja te nižeg samopoštovanja i religioznosti slati seksualizirane poruke. S obzirom se na socijalnu osjetljivost očekuje da će roditeljska kontrola, tip škole i obrazovanje roditelja imati učinak u predviđanju slanja seksualiziranih poruka, tako što ce adolescenti koji izvještavaju o manjoj izraženosti roditeljske kontrole, učenici tehničkih zanimanja te oni čiji su roditelji postigli niži stupanj obrazovanja, slati seksualizirane poruke. Očekuje se i da će seksualna inicijacija, korištenje SEM-a i korištenje internetskih 
društvenih mreža upućivati na veću vjerojatnost slanja seksualiziranih poruka. Adolescenti koji su spolno aktivni, češće koriste SEM i koji provode više vremena na društvenim mrežama će biti skloniji slanju seksualiziranih poruka. S obzirom na to da su socijalizacijski procesi i dalje velikim dijelom spolno specifični (Valkenburg i Peter, 2013), sve će se analize raditi posebno za mladiće i djevojke.

\section{Metoda}

\section{Sudionici}

Istraživanje je provedeno na populacijskom uzorku učenika drugih razreda srednjih škola u Rijeci. Umjesto tzv. akceleriranoga longitudinalnog dizajna korišten je pristup dobne kohorte, koji kroz vrijeme prati specifičnu dobnu skupinu. Za početnu su dob izabrani 16-ogodišnjaci jer je to dob prije nego prosječan adolescent u Hrvatskoj postane seksualno aktivna osoba (Træen, Stulhofer i Landripet, 2011). Razlozi su za odabrani pristup dvojaki: prvi je interes za promjene vezane za tranziciju iz faze srednje adolescencije u fazu kasne adolescencije (što je u kontekstu seksualne aktivacije ključno razdoblje), a drugi je činjenica da bi akcelerirani dizajn rezultirao manjom statističkom snagom analiza u kojima je fokus na sudionicima koji su već imali prvi seksualni odnos.

U prvom je mjerenju sudjelovalo 1307 učenika, a u drugom 1252. Kada su iz analize izuzeti nepotpuni upitnici i kada su učenici upareni po šiframa, ostao je 791 sudionik, od toga 301 mladić (38.2\%) i 489 djevojka (61.8\%). Raspon je dobi od 15 do 18 godina $(M=15.82 ; S D=0.51)$. Od ukupnog broja sudionika $31.5 \%$ učenika pohađa gimnazije a $68.5 \%$ strukovne škole. Prvo je mjerenje pokazalo da je $18.5 \%$ sudionika imalo spolni odnos, a 54.9\% ih je koristilo SEM u proteklih šest mjeseci, dok je u drugom mjerenju $25.3 \%$ ispitanika bilo spolno aktivno te ih je također $54.9 \%$ koristilo SEM između prvog i drugog mjerenja. Kod ispitivanja učestalosti slanja seksualno eksplicitnih poruka $46 \%$ mladića je u prvom i $37.7 \%$ u drugom mjerenju bar jednom poslalo takvu poruku, dok je isto ponašanje označilo $36.6 \%$ djevojaka u prvom i $33.7 \%$ u drugom mjerenju.

\section{Instrumentarij}

U istraživanju su korišteni mjerni instrumenti konstruirani za potrebe projekta Prospective Biopsychosocial Study of the Effects of Sexually Explicit Material on Young People's Sexual Socialization and Health (PROBIOPS) ${ }^{1}$ Riječ je o longitudinalnom istraživanju učinaka seksualiziranih medija na stavove, ponašanje i vjerovanja mladih.

\footnotetext{
${ }^{1}$ Rad je dio projekta PROBIOPS, koji financira Hrvatska zaklada za znanost (br. 9221).
} 
Prikupljeni su sociodemografski podatci: spol, dob ispitanika, vrsta srednje škole (gimnazija ili strukovna škola) i postignuti stupanj obrazovanja roditelja, koji je naknadno rekodiran u dvije kategorije: roditelji koji su završili srednju školu i/ili manje te roditelji koji su završili fakultet.

Roditeljska kontrola mjerena je Upitnikom roditeljske kontrole, koji je prethodno validiran na uzorku mladih u istraživanju koje su proveli Landripet, Baćak i Štulhofer (2011). Upitnik sadrži četiri tvrdnje, a zadatak je sudionika bio procjena stupnja slaganja na ljestvici Likertova tipa od 1 (Uopće se ne odnosi na mene) do 5 (U potpunosti se odnosi na mene). Primjer je tvrdnje ovog upitnika Moji roditelji znaju kamo izlazim navečer. Ukupni je rezultat jednostavna linearna kombinacija odgovora na svim tvrdnjama, raspona od 4 do 20 , gdje viši rezultati upućuju na veću roditeljsku kontrolu. Pouzdanost tipa unutarnje konzistencije u prvom mjerenju iznosi .78, dok koeficijent stabilnosti iznosi .66.

Samopoštovanje je mjereno Kratkim upitnikom samoopisivanja, koji je prilagođena verzija Self-Description Questionnaire-a (Cenat i sur., 2014). Upitnik je za potrebe projekta PROBIOPS preveo i prilagodio istraživački tim sastavljen od psihologa i sociologa. Upitnik sadrži četiri tvrdnje, a zadatak je sudionika bila procjena stupnja slaganja na ljestvici Likertova tipa od 1 (Uopće se ne odnosi na mene) do 5 (U potpunosti se odnosi na mene). Primjer tvrdnje ovog upitnika je $U$ cjelini, mogu se ponositi sobom. Ukupni je rezultat jednostavna linearna kombinacija odgovora na svim tvrdnjama, raspona rezultata od 4 do 20 , gdje viši rezultati upućuju na više samopoštovanje. Pouzdanost tipa unutarnje konzistencije u prvom mjerenju iznosi .81, dok koeficijent stabilnosti iznosi .65.

Anksioznost $i$ depresivnost mjerene su Kratkim upitnikom anksioznosti i depresivnosti, koji je prilagođena verzija Patient Health Questionnaire for Depression and Anxiety (PHQ-4; Kroenke, Spitzer, Williams i Lowe, 2009). Upitnik je za potrebe ovog istraživanja na hrvatski jezik preveo istraživački tim projekta PROBIOPS. Upitnik sadrži ukupno četiri tvrdnje, po dvije za ispitivanje prisutnosti simptoma anksioznosti i dvije za ispitivanje prisutnosti simptoma depresivnosti, a zadatak je sudionika bila procjena učestalosti pojavljivanja navedenih simptoma, $\mathrm{u}$ protekla dva tjedna, na ljestvici od 1 (Uopće ne) do 4 (Gotovo svaki dan). Primjer je tvrdnje ovog upitnika za ispitivanje anksioznosti Osjećao/la sam se nervozno ili napeto., a za ispitivanje depresivnosti Nisu me baš zanimale ni veselile stvari koje sam radio/la. Ukupni je rezultat jednostavna linearna kombinacija odgovora na svim tvrdnjama, raspona rezultata od 4 do 16 , gdje viši rezultat upućuje na izraženije simptome. Ova se mjera pokazala vrlo dobrom za ispitivanje simptoma anksioznosti i depresivnosti jer iako je kratka, sadrži ključne kriterije za ispitivanje ovih simptoma (Kroenke, Spitzer, Williams, Monahan i Lowe, 2007). S obzirom na to da postoji značajno preklapanje simptoma anksioznosti i depresivnosti u istraživanjima i kliničkoj praksi (Lamers i sur., 2011), te sukladno dobivenom jednofaktorskom strukturom u predistraživanju na uzorku srednjoškolaca Grada Zagreba, u daljnjim se analizama ovaj upitnik koristio kao jednodimenzionalna mjera. Pouzdanost tipa 
unutarnje konzistencije u prvom mjerenju iznosi .84 , dok koeficijent stabilnosti iznosi .54.

Traženje uzbuđenja mjereno je Kratkim upitnikom traženja uzbuđenja, koji je prilagođena verzija upitnika Brief Sensation Seeking Scale (BSSS-4; Stephenson, Hoyle, Palmgreen i Slater, 2003). Upitnik je za potrebe projekta PROBIOPS preveo i prilagodio istraživački tim psihologa i sociologa. U upitniku su navede četiri tvrdnje, a zadatak je ispitanika bila procjena stupnja slaganja na ljestvici Likertova tipa od 1 (Uopće se ne odnosi na mene) do 5 (U potpunosti se odnosi na mene). Primjer je tvrdnje ovog upitnika Volim raditi stvari koje su drugima zastrašujuće. Ukupni je rezultat jednostavna linearna kombinacija odgovora na svim tvrdnjama, raspona rezultata od 4 do 20 , gdje viši rezultati upućuju na izraženiju sklonost traženju uzbuđenja. Pouzdanost tipa unutarnje konzistencije u prvom mjerenju iznosi .76 , dok koeficijent stabilnosti iznosi .66.

Religioznost je mjerena prilagođenom verzijom Kratke ljestvice religioznosti, koja je prethodno validirana na uzorku hrvatskih adolescenata (Bezinović, Marinović Bobinac i Marinović Jerolimov, 2005). U odnosu na ljestvicu izvornih autora (Bezinović i sur., 2005) prilagođena je verzija dobivena izbacivanjem jedne čestice što se pokazalo potrebnim $u$ analizi pouzdanosti $u$ istraživanju provedenom na uzorku hrvatskih adolescenata (Štulhofer, Šoh, Jelaska, Baćak i Landripet, 2011). Upitnik sadrži četiri tvrdnje (npr. Vjera mi pomaže da lakše podnosim životne teškoće $i$ probleme), a zadatak je sudionika bila procjena stupnja slaganja na ljestvici Likertova tipa od 1 (Uopće se ne odnosi na mene) do 5 (U potpunosti se odnosi na mene). Ukupni je rezultat jednostavna linearna kombinacija odgovora na svim tvrdnjama, raspona rezultata od 4 do 20 , gdje viši rezultati upućuju na izraženiju religioznost. Pouzdanost tipa unutarnje konzistencije u prvom mjerenju iznosi .92, dok koeficijent stabilnosti iznosi .85 .

Seksualna inicijacija ispitana je pitanjem jesu li do trenutka mjerenja ikada imali spolni odnos (snošaj), a mogući su odgovori bili da ili ne.

Korištenje internetskih društvenih mreža ispitano je sljedećom tvrdnjom: $U$ prosjeku, koliko sati dnevno provedeš na društvenim mrežama (Facebook, Twitter, Instagram $i$ sl.)? Zadatak sudionika bio je upisati broj sati na za to predviđeno mjesto, uz uputu da upišu "0" ako ne provode vrijeme na društvenim mrežama.

Seksualno eksplicitan materijal (SEM) definiran je kao svi materijali koji izravno i otvoreno prikazuju spolni odnos, odnosno različite seksualne aktivnosti. Učestalost korištenja SEM-a ispitana je sljedećom tvrdnjom: $U$ posljednjih 6 mjeseci koliko si često koristio pornografiju?, a procjenjivalo se na ljestvici od 1 (Niti jednom) do 8 (Više puta dnevno).

Slanje seksualiziranih poruka mjerilo se prilagođenom verzijom ljestvice konstruiranom za potrebe projekta PROBIOPS, koja je prethodno korištena na uzorku hrvatskih adolescenata (Tomić i sur., 2018). Originalna ljestvica sadrži četiri tvrdnje koje ispituju učestalost slanja seksualiziranih poruka nekome, slanja vlastitih seksualnih fotografija i videa te slanja pornografskih fotografija ili videa, s tim da je 
u prilagođenoj verziji posljednja tvrdnja koja ispituje slanje pornografskih fotografija ili videa izbačena iz daljnje analize jer, prema standardnoj definiciji, ne predstavlja slanje seksualiziranih poruka. Zadatak je sudionika bio na ljestvici od 1 (Nijednom) do 5 (Šest ili više puta) označiti čestinu ponašanja u proteklih šest mjeseci. Ukupni je rezultat jednostavna linearna kombinacija odgovora na svim tvrdnjama, raspona rezultata od 3 do 15, gdje viši rezultati upućuju na češće slanje seksualiziranih poruka. Pouzdanost tipa unutarnje konzistencije u prvom mjerenju iznosi .67, a u drugom .71., dok koeficijent stabilnosti iznosi .46. S obzirom je na odstupanje u normalnosti distribucije, slanje seksualiziranih poruka iz oba mjerenja naknadno rekodirano u dvije kategorije: mladi koji nikada nisu poslali seksualiziranu poruku te mladi koji su poslali bar jednu takvu poruku. Od ukupnog broja mladića u prvom mjerenju njih 54\% nijednom nije slalo seksualizirane poruke, dok je u drugom mjerenju njih $62.3 \%$ označilo da nijednom nisu slali takve poruke u proteklih 6 mjeseci. Na poduzorku djevojaka u prvom mjerenju njih $63.4 \%$ nijednom nije slalo seksualizirane poruke, dok je u drugom mjerenju njih $66.3 \%$ označilo takav odgovor.

$\mathrm{S}$ obzirom na to da je ovo istraživanje dio većega longitudinalnog projekta, korištene su kratke mjere kako bi se smanjio umor sudionika, broj preskočenih pitanja, ali i što manje opteretilo izvođenje nastave u školama. Iz toga su razloga korišteni primarno upitnici prethodno validirani na uzorcima adolescenata (npr. samopoštovanje i traženje uzbuđenja). Skraćivanje je upitnika bilo vođeno uvidom u faktorsku strukturu mjera, analizom pouzdanosti te provođenjem predistraživanja $u$ usporednom (online) panel-uzroku srednjoškolaca Grada Zagreba.

\section{Postupak}

Suglasnost o provođenju istraživanja dalo je Etičko povjerenstvo Filozofskog fakulteta u Zagrebu te Ministarstvo znanosti, obrazovanja i sporta, a potporu je dala i pravobraniteljica za djecu. Istraživanje je provedeno u 14 srednjih škola u Rijeci. Svi su roditelji pismeno informirani o predmetu, ciljevima i načinu provođenja istraživanja, a kako su učenici drugih razreda stariji od 14 godina, tražen je njihov usmeni pristanak. U slučaju da su roditelji odbili sudjelovanje svoga djeteta $\mathrm{u}$ istraživanju, taj je zahtjev uvažen. Dvoje je istraživača distribuiralo i nadgledalo ispunjavanje upitnika u svakom razredu svih srednjih škola. Usmeno i pismeno na početku svakog upitnika sudionici su bili informirani kako je sudjelovanje dobrovoljno te su mogli odustati u bilo kojem trenutku. Naglašeno im je da mogu upitati istraživača za nejasnoće vezane za pitanja i uputu. Kako bi se osigurala povjerljivost $\mathrm{i}$ anonimnost, sudionici su bili odvojeni panelima $(50 \times 50 \mathrm{~cm})$ postavljenima na sredinu školskih klupa. Svaki je sudionik na početku upitnika trebao upisati jedinstvenu šifru kako bi se mogli uparivati odgovori između mjerenja. Ispunjavanje se odvijalo za vrijeme nastave, trajalo je u prosjeku 20 minuta, a istraživači su imali na raspolaganju cijeli školski sat. Prvo je mjerenje provedeno tijekom prosinca 2015., a treće tijekom listopada 2016. S obzirom na to da se u radu 
koriste podaci samo iz dva navedena mjerenja, mjerenje iz prosinca u nastavku rada zovemo prvim, a mjerenje iz listopada drugim mjerenjem ili valom.

\section{Rezultati}

Imajući u vidu da je riječki uzorak temeljen na klasterima (škole i razredi), što znači da su standardne pogreške procjena sustavno podcijenjene zbog utjecaja tzv. interklasne korelacije (Harris, 1997), multivarijatne su analize provedene uporabom modula complex sampling u programu IBM SPSS 23. Na taj su način u provedenim linearnim regresijskim analizama robusne standardne pogreške korigirane s obzirom na specifičnu strategiju uzorkovanja (u odnosu na jednostavni slučajni uzorak kao zlatni standard), ali i za heteroscedastičnost reziduala. Deskriptivni podatci o korištenim indikatorima te njihova međusobna povezanost prikazani su u Tablici 1. i 2 .

Tablica 1.

Prikaz deskriptivnih parametara mjerenih varijabli

\begin{tabular}{lcccc}
\hline & \multicolumn{2}{c}{$M$} & \multicolumn{2}{c}{$S D$} \\
\cline { 2 - 5 } & mladići & djevojke & mladići & djevojke \\
\hline Roditeljska kontrola & 16.98 & 17.34 & 2.92 & 2.67 \\
Samopoštovanje & 16.61 & 15.28 & 2.43 & 2.79 \\
Traženje uzbuđenja & 13.03 & 13.23 & 3.72 & 3.59 \\
Anksioznost i depresivnost & 7.69 & 9.43 & 2.76 & 3.31 \\
Religioznost & 12.03 & 11.89 & 5.12 & 5.09 \\
Korištenje online društvenih mreža & 2.83 & 3.96 & 2.18 & 2.58 \\
Korištenje SEM-a & 4.76 & 1.61 & 2.08 & 1.12 \\
SSP T1 & 4.65 & 4.17 & 2.60 & 2.05 \\
SSP T2 & 4.43 & 4.18 & 2.54 & 2.11 \\
\hline
\end{tabular}

Legenda: SEM - seksualno eksplicitni materijal; SSP - slanje seksualiziranih poruka; T1 - prvo mjerenje; T2 - drugo mjerenje

$\mathrm{U}$ ispitivanju povezanosti slanja seksualiziranih poruka s ostalim varijablama rezultati su pokazali kako je traženje uzbuđenja i stupanje u spolni odnos pozitivno povezano sa slanjem seksualiziranih poruka u oba mjerenja i kod mladića i kod djevojaka. Nadalje, u oba su mjerenja na poduzorku mladića roditeljska kontrola i religioznost negativno povezani sa slanjem seksualiziranih poruka, dok su, također u oba mjerenja, anksioznost i depresivnost, korištenje internetskih društvenih mreža te korištenje SEM-a pozitivno povezani sa slanjem seksualiziranih poruka. Rezultati su djelomično konzistentni na poduzorku djevojaka. U oba je mjerenja samopoštovanje pozitivno povezano sa slanjem seksualiziranih poruka, dok je roditeljska kontrola

\footnotetext{
${ }^{2}$ Aritmetička sredina i standardna devijacija odnose se na SSP T1 i T2 prije dihotomiziranja.
} 


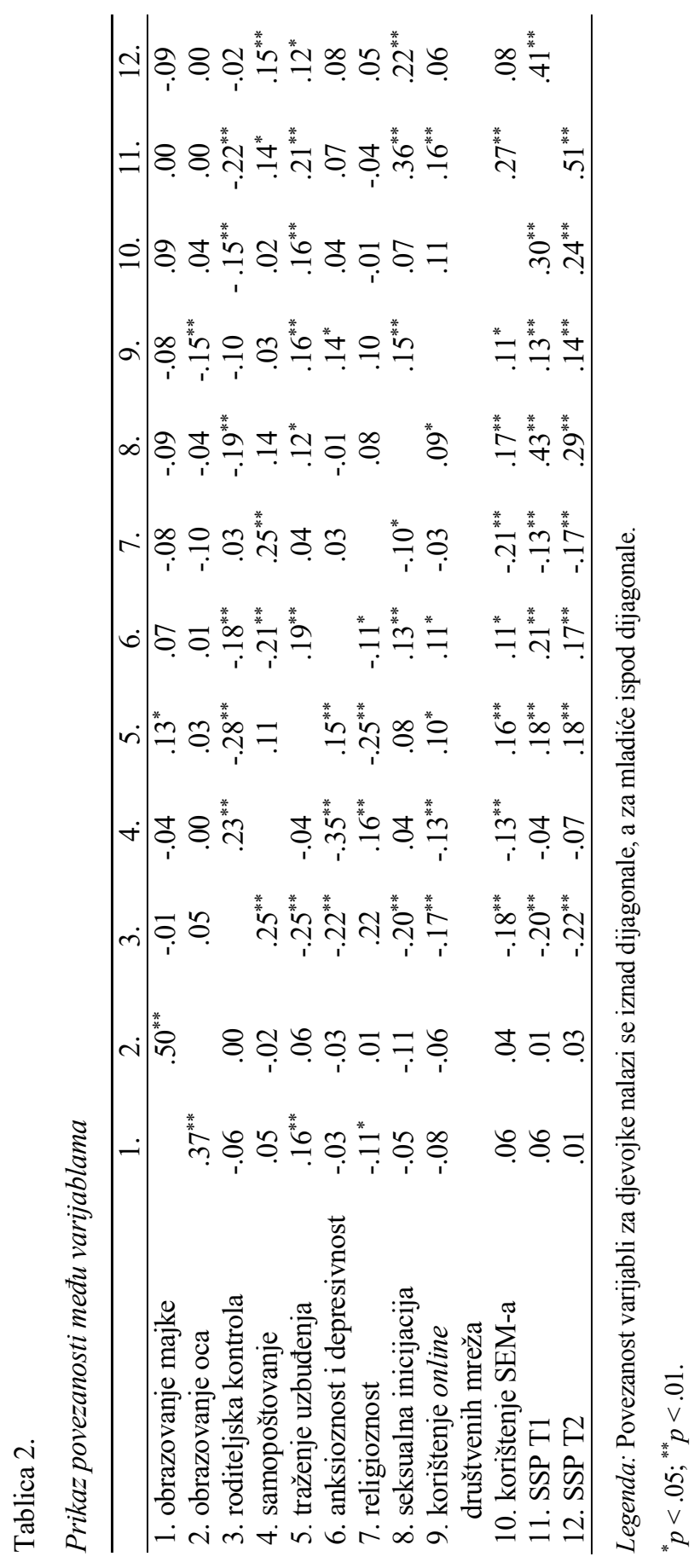


negativno, a korištenje internetskih društvenih mreža i korištenje SEM-a pozitivno povezano sa slanjem seksualiziranih poruka samo u prvom mjerenju.

Kada su u pitanju povezanosti među prediktorima, roditeljska se kontrola pokazala pozitivno povezanom sa samopoštovanjem i korištenjem SEM-a, a negativno $\mathrm{s}$ traženjem uzbuđenja, anksioznosti i depresivnosti te seksualnom inicijacijom kod djevojaka. Roditeljska je kontrola kod mladića pozitivno povezana sa samopoštovanjem, a negativno $\mathrm{s}$ traženjem uzbuđenja, anksioznosti i depresivnosti, seksualnom inicijacijom, korištenjem internetskih društvenih mreža i korištenjem SEM-a. Samopoštovanje je kod djevojaka pozitivno povezano $\mathrm{s}$ religioznosti, a negativno s anksioznosti i depresivnosti. Kod mladića je dobivena pozitivna povezanost $\mathrm{s}$ religioznosti, a negativna s anksioznosti i depresivnosti, korištenjem internetskih društvenih mreža te korištenjem SEM-a. Traženje uzbuđenja kod djevojaka je pozitivno povezano s anksioznosti i depresivnosti, seksualnom inicijacijom, korištenjem internetskih društvenih mreža te korištenjem SEM-a. Kod mladića je dobivena pozitivna povezanost $s$ anksioznosti i depresivnosti, korištenjem internetskih društvenih mreža te korištenjem SEM-a, a negativna s religioznosti. Anksioznost i depresivnost su kod djevojaka pozitivno povezane samo $\mathrm{s}$ korištenjem internetskih društvenih mreža. Kod mladića je dobivena pozitivna povezanost sa seksualnom inicijacijom, korištenjem internetskih društvenih mreža te korištenjem SEM-a, a negativna s religioznosti. Religioznost je kod mladića negativno povezana sa seksualnom inicijacijom i korištenjem SEM-a. Seksualna je inicijacija kod djevojaka pozitivno povezana s korištenjem internetskih društvenih mreža, a kod mladića, osim što je također pozitivno povezana $\mathrm{s}$ korištenjem internetskih društvenih mreža, povezana je i s korištenjem SEM-a.

Kako bi ispitali u kojoj mjeri tip škole, obiteljska okolina, individualna obilježja, seksualna iskustva te upotreba medija predviđa slanje seksualiziranih poruka 12 mjeseci nakon inicijalnog mjerenja, provedene su autoregresivne hijerarhijske logističke regresijske analize odvojeno po spolu. Rezultati su prikazani u Tablici 3. i 4.

Tablica 3.

Rezultati hijerarhijske logističke regresijske analize za kriterijsku varijablu učestalost slanja seksualiziranih poruka u drugom mjerenju za djevojke

\begin{tabular}{lccccccc}
\hline & $B$ & $S E B$ & $\begin{array}{c}\text { Waldov } \\
\text { test }\end{array}$ & $\operatorname{Exp}(B)$ & $95 \% C I$ & $\chi^{2} / d f$ & Nagelkerke \\
\hline 1. korak & & & & & & & \\
\hline SSP T1 & $2.28^{* *}$ & 0.21 & 114.66 & 9.81 & $6.39-15.04$ & $114.66 / 1$ & .31 \\
\hline 2. korak & & & & & & & \\
\hline SSP T1 & $2.22^{* *}$ & 0.22 & 105.90 & 9.22 & $5.98-14.21$ & $133.36 / 5$ & .36 \\
traženje & $0.12^{* *}$ & 0.03 & 11.51 & 1.12 & $1.05-1.20$ & & \\
uzbuđenja & & & & & & & \\
samopoštovanje & -0.05 & 0.04 & 1.73 & 0.95 & $0.88-1.03$ & & \\
religioznost & $-0.06^{* *}$ & 0.02 & 6.91 & 0.94 & $0.90-0.99$ & & \\
$\begin{array}{l}\text { anksioznost i } \\
\text { depresivnost }\end{array}$ & 0.01 & 0.04 & 0.15 & 1.01 & $0.94-1.09$ & & \\
\hline
\end{tabular}


Tablica 3. - Nastavak

\begin{tabular}{|c|c|c|c|c|c|c|c|}
\hline & $B$ & $S E B$ & $\begin{array}{c}\text { Waldov } \\
\text { test }\end{array}$ & $\operatorname{Exp}(B)$ & $95 \% C I$ & $\chi^{2} / d f$ & Nagelkerke \\
\hline \multicolumn{8}{|l|}{ 3. korak } \\
\hline SSP T1 & $2.26^{* *}$ & 0.21 & 120.33 & 9.57 & $6.32-14.46$ & $156.77 / 9$ & .37 \\
\hline $\begin{array}{l}\text { traženje } \\
\text { uzbuđenja }\end{array}$ & $0.11^{* *}$ & 0.04 & 10.24 & 1.12 & $1.04-1.20$ & & \\
\hline samopoštovanje & -0.02 & 0.04 & 0.30 & 0.98 & $0.90-1.06$ & & \\
\hline religioznost & $-0.05^{*}$ & 0.02 & 5.56 & 0.95 & $0.91-0.99$ & & \\
\hline $\begin{array}{l}\text { anksioznost i } \\
\text { depresivnost }\end{array}$ & 0.01 & 0.04 & 0.06 & 1.01 & 0.93-1.09 & & \\
\hline $\begin{array}{l}\text { tip škole } \\
(1=\text { gimnazija })\end{array}$ & 0.07 & 0.25 & 0.08 & 1.07 & $0.65-1.76$ & & \\
\hline $\begin{array}{l}\text { obrazovanje } \\
\text { majke }\end{array}$ & -0.03 & 0.35 & 0.01 & 0.97 & $0.48-1.96$ & & \\
\hline $\begin{array}{l}\text { obrazovanje oca } \\
(1=<\mathrm{SSS})\end{array}$ & -0.41 & 0.33 & 1.58 & 0.67 & $0.35-1.28$ & & \\
\hline $\begin{array}{l}\text { roditeljska } \\
\text { kontrola }\end{array}$ & -0.04 & 0.06 & 0.48 & 0.96 & $0.86-1.08$ & & \\
\hline \multicolumn{8}{|l|}{ 4. korak } \\
\hline SSP T1 & $1.94^{* *}$ & 0.23 & 74.31 & 6.96 & $4.43-10.93$ & $182.08 / 12$ & .41 \\
\hline $\begin{array}{l}\text { traženje } \\
\text { uzbuđenja }\end{array}$ & $0.11^{* *}$ & 0.04 & 10.17 & 1.12 & $1.04-1.20$ & & \\
\hline samopoštovanje & -0.05 & 0.05 & 1.06 & 0.96 & $0.87-1.04$ & & \\
\hline religioznost & -0.04 & 0.03 & 2.91 & 0.96 & $0.91-1.01$ & & \\
\hline $\begin{array}{l}\text { anksioznost i } \\
\text { depresivnost }\end{array}$ & 0.01 & 0.01 & 0 & 1.00 & $0.93-1.08$ & & \\
\hline $\begin{array}{l}\text { tip škole } \\
(1=\text { gimnazija })\end{array}$ & -0.04 & 0.26 & 0.21 & 0.96 & $0.57-1.62$ & & \\
\hline $\begin{array}{l}\text { obrazovanje } \\
\text { majke } \\
(1=<\mathrm{SSS})\end{array}$ & -0.02 & 0.36 & 0.01 & 0.98 & $0.47-2.03$ & & \\
\hline $\begin{array}{l}\text { obrazovanje oca } \\
(1=<\mathrm{SSS})\end{array}$ & -0.31 & 0.33 & 0.89 & 0.74 & $0.38-1.41$ & & \\
\hline $\begin{array}{l}\text { roditeljska } \\
\text { kontrola }\end{array}$ & -0.01 & 0.06 & 0.06 & 0.99 & $0.88-1.11$ & & \\
\hline $\begin{array}{l}\text { seksualna } \\
\text { inicijacija } \\
(1=\mathrm{Ne})\end{array}$ & $1.14^{* *}$ & 0.31 & 13.84 & 3.13 & $1.69-5.79$ & & \\
\hline $\operatorname{SEM}^{3}(1=\mathrm{Ne})$ & $0.64^{*}$ & 0.29 & 4.81 & 1.89 & $1.06-3.39$ & & \\
\hline $\begin{array}{l}\text { korištenje online } \\
\text { društvenih mreža }\end{array}$ & 0.01 & 0.04 & 0.06 & 1.01 & $0.93-1.10$ & & \\
\hline
\end{tabular}

Legenda: SSP T1 - slanje seksualiziranih poruka prvo mjerenje; SEM - seksualno eksplicitni materijal; $1-$ referentna kategorija; ${ }^{*} p<.05 ;{ }^{* *} p<.01$.

${ }^{3}$ Varijabla SEM je kod djevojaka kodirana u dvije kategorije zbog odstupanja od očekivane distribucije. Koristeći opciju "visual binning", dobiveno je kako dvije kategorije najbolje opisuju sudionike, zbog toga što postoji podjednak broj djevojaka koji nikada ne koriste SEM i koje koriste SEM. 
Model se sastojao od četiri koraka. Kako bi se pri predikciji ishoda kontrolirala ranija praksa, slanje je seksualiziranih poruka u prvom mjerenju uvršteno u sve korake. Ranija praksa slanja seksualiziranih poruka objašnjava ukupno $31 \%$ varijance kriterija. U drugom su koraku uvrštene varijable koje se odnose na dispozicijsku osjetljivost (traženje uzbuđenja, samopoštovanje, religioznost te anksioznost i depresivnost), a objašnjavaju dodatno 5\% varijance kriterija. U trećem su koraku uvrštene varijable koje se odnose na socijalnu osjetljivost (tip škole, obrazovanje majke i oca te roditeljska kontrola), a objašnjavaju dodatno svega $1 \%$ varijance kriterija. U posljednjem su koraku uvrštene ponašajne varijable (seksualna inicijacija, korištenje internetskih društvenih mreža te uporaba SEM-a), koje dodatno objašnjavaju 4\% varijance kriterija. Kada je riječ o djevojkama, u završnom su koraku kao značajni pozitivni prediktori slanja seksualiziranih poruka, uz njihovo ranije prakticiranje, utvrđeni traženje uzbuđenja, iskustvo seksualnog odnosa te uporaba SEM-a.

Tablica 4.

Rezultati hijerarhijske logističke regresijske analize za kriterijsku varijablu učestalost slanja seksualiziranih poruka u drugom mjerenju za mladiće

\begin{tabular}{|c|c|c|c|c|c|c|c|}
\hline & $B$ & $S E B$ & $\begin{array}{l}\text { Waldov } \\
\text { test }\end{array}$ & $\operatorname{Exp}(B)$ & $95 \% C I$ & $\chi^{2} / d f$ & Nagelkerke \\
\hline \multicolumn{8}{|l|}{ 1. korak } \\
\hline SSP T1 & $1.98^{* *}$ & & 61.81 & 7.27 & $4.38-12.08$ & $61.81 / 1$ & .25 \\
\hline \multicolumn{8}{|l|}{ 2. korak } \\
\hline SSP T1 & $1.86^{* *}$ & 0.28 & 45.06 & 6.42 & $3.68-11.20$ & $56.12 / 5$ & .28 \\
\hline $\begin{array}{l}\text { traženje } \\
\text { uzbuđenja }\end{array}$ & 0.05 & 0.04 & 1.58 & 1.05 & $0.97-1.13$ & & \\
\hline samopoštovanje & 0.08 & 0.08 & 1.16 & 1.08 & $0.97-1.13$ & & \\
\hline religioznost & 0.06 & 0.03 & 2.82 & 1.06 & $0.99-1.13$ & & \\
\hline $\begin{array}{l}\text { anksioznost i } \\
\text { depresivnost }\end{array}$ & 0.04 & 0.05 & 0.75 & 1.04 & $0.95-1.14$ & & \\
\hline \multicolumn{8}{|l|}{ 3. korak } \\
\hline SSP T1 & $2.04^{* *}$ & 0.34 & 36.20 & 7.66 & $3.88-15.12$ & $53.21 / 9$ & .32 \\
\hline $\begin{array}{l}\text { traženje } \\
\text { uzbuđenja }\end{array}$ & 0.08 & 0.04 & 3.39 & 1.08 & $0.99-1.18$ & & \\
\hline samopoštovanj & 0.05 & 0.08 & 0.35 & 1.05 & $0.89-1.22$ & & \\
\hline religioznost & 0.05 & 0.04 & 1.81 & 1.05 & $0.98-1.13$ & & \\
\hline $\begin{array}{l}\text { anksioznost i } \\
\text { depresivnost }\end{array}$ & 0.06 & 0.05 & 1.32 & 1.06 & $0.96-1.16$ & & \\
\hline $\begin{array}{l}\text { tip škole } \\
\text { (1 = gimnazija) }\end{array}$ & 0.54 & 0.51 & 1.12 & 1.72 & $0.62-4.82$ & & \\
\hline $\begin{array}{l}\text { obrazovanje } \\
\text { majke } \\
(1=<\mathrm{SSS})\end{array}$ & -0.51 & 0.35 & 2.09 & 0.60 & $0.30-1.22$ & & \\
\hline $\begin{array}{l}\text { obrazovanje oca } \\
(1=<\mathrm{SSS})\end{array}$ & 0.16 & 0.39 & 0.16 & 1.17 & $0.54-2.56$ & & \\
\hline $\begin{array}{l}\text { roditeljska } \\
\text { kontrola }\end{array}$ & 0.09 & 0.06 & 2.47 & 1.01 & $0.97-1.24$ & & \\
\hline
\end{tabular}


Tablica 4. - Nastavak

\begin{tabular}{|c|c|c|c|c|c|c|c|}
\hline & $B$ & $S E B$ & $\begin{array}{c}\text { Waldov } \\
\text { test }\end{array}$ & $\operatorname{Exp}(B)$ & $95 \% C I$ & $\chi^{2} / d f$ & Nagelkerke \\
\hline \multicolumn{8}{|l|}{ 4. korak } \\
\hline SSP T1 & $2.10^{* *}$ & 0.37 & 31.42 & 8.17 & $3.85-17.36$ & $53.91 / 12$ & .34 \\
\hline $\begin{array}{l}\text { traženje } \\
\text { uzbuđenja }\end{array}$ & $0.09^{*}$ & 0.04 & 4.05 & 1.09 & $1.00-1.19$ & & \\
\hline samopoštovanje & 0.02 & 0.07 & 0.08 & 1.02 & $0.88-1.18$ & & \\
\hline religioznost & 0.05 & 0.04 & 2.09 & 1.05 & $0.98-1.13$ & & \\
\hline $\begin{array}{l}\text { anksioznost i } \\
\text { depresivnost }\end{array}$ & 0.06 & 0.05 & 1.40 & 1.06 & $0.96-1.16$ & & \\
\hline $\begin{array}{l}\text { tip škole } \\
\text { (1=gimnazija) }\end{array}$ & 0.49 & 0.51 & 0.92 & 1.63 & $0.58-4.58$ & & \\
\hline $\begin{array}{l}\text { obrazovanje } \\
\text { majke } \\
(1=<\mathrm{SSS})\end{array}$ & -0.44 & 0.36 & 1.51 & 0.64 & $0.31-1.32$ & & \\
\hline $\begin{array}{l}\text { obrazovanje oca } \\
(1=<\mathrm{SSS})\end{array}$ & 0.12 & 0.39 & 0.11 & 1.13 & $0.52-2.49$ & & \\
\hline roditeljska & 0.11 & 0.06 & 3.04 & 1.11 & $0.98-1.26$ & & \\
\hline $\begin{array}{l}\text { kontrola } \\
\text { seksualna } \\
\text { inicijacija }(1=\mathrm{Ne})\end{array}$ & 0.45 & 0.37 & 1.47 & 1.56 & $0.75-3.28$ & & \\
\hline $\operatorname{SEM}^{4}(1=$ ne & & & 1.75 & 1 & & & \\
\hline $2=$ ponekad & 0.53 & 0.74 & & 0.98 & $0.21-4.70$ & & \\
\hline $3=$ često) & 0.52 & 0.29 & & 0.59 & $0.13-2.69$ & & \\
\hline $\begin{array}{l}\text { korištenje online } \\
\text { društvenih mreža }\end{array}$ & -0.01 & 0.08 & 0.03 & 0.99 & $0.84-1.16$ & & \\
\hline
\end{tabular}

Legenda: SSP T1 - slanje seksualiziranih poruka prvo mjerenje; SEM - seksualno eksplicitni materijal; 1 - referentna kategorija; ${ }^{*} p<.05 ;{ }^{* *} p<.01$.

Za razliku od djevojaka u poduzorku je mladića slanje seksualno eksplicitnih poruka $\mathrm{u}$ drugom mjerenju bilo značajno povezano $\mathrm{s}$ ranijom praksom slanja seksualno eksplicitnih poruka i traženjem uzbuđenja. Ranija praksa slanja seksualiziranih poruka objašnjava $25 \%$ varijance kriterija, dok posljednji korak objašnjava $9 \%$ varijance kriterija. S obzirom na to da je traženje uzbuđenja postao značajan prediktor tek nakon uvođenja varijable korištenja SEM-a, provjerena je povezanost traženja uzbuđenja s kriterijem s obzirom na razine učestalosti korištenja SEM-a. Rezultati su pokazali kako je ta povezanost statistički značajna isključivo kod onih ispitanika koji rjeđe koriste $\operatorname{SEM}(r=.20, p<.01)$.

\footnotetext{
${ }^{4}$ Varijabla SEM je kod mladića kodirana u tri kategorije zbog odstupanja od očekivane distribucije. Koristeći opciju "visual binning", dobiveno je kako tri kategorije najbolje opisuju sudionike jer postoji podjednak broj mladića koji nikada ne koriste SEM, koji ponekad koriste SEM i koji često koriste SEM.
} 


\section{Rasprava}

S ciljem što boljeg razumijevanja relativno novog fenomena vezanog uz razvoj mobilnih tehnologija, mnoga su se istraživanja bavila obilježjima mladih koji su skloniji slanju seksualiziranih poruka i prediktorima takva ponašanja. Rezultati, međutim, nisu uvijek konzistentni. To je bio poticaj za provođenje ovoga longitudinalnog istraživanja, kojim se željelo ispitati moguće varijable koje longitudinalno predviđaju praksu slanja seksualiziranih poruka. Vodeći se modelom diferencijalne osjetljivosti na efekte medija (DSMM; Valkenburg i Peter, 2013), cilj je bio ispitati doprinose varijabli koje se odnose na dispozicijsku osjetljivost (traženje uzbuđenja, samopoštovanje, religioznost te anksioznost i depresivnost), varijabli koje se odnose na socijalnu osjetljivost (tip škole, obrazovanje majke i oca te roditeljska kontrola) te ponašajnih varijabli (seksualna inicijacija, korištenje internetskih društvenih mreža te uporaba SEM-a) u objašnjenju slanja seksualiziranih poruka kod adolescenata. U kontekstu su DSMM-a (Valkenburg i Peter, 2013) u ovom radu korištene dvije vrste diferencijalno-osjetljivih indikatora, dispozicijske i socijalne. Dispozicijska i socijalna osjetljivost odnose se na one dimenzije koje predisponiraju osobe k određenom odabiru i reagiranju na medije poput spola, različitih crta ličnosti, raspoloženja, ali i socijalno-kontekstualnih čimbenika poput obiteljske okoline i škole.

Rezultati su provedenog istraživanja među mladićima i djevojkama pokazali da se kod ispitivanja relevantnosti različitih dispozicijskih varijabli samo traženje uzbuđenja pokazalo značajnim pozitivnim prediktorom slanja seksualiziranih poruka godinu dana nakon inicijalnog mjerenja. Taj se nalaz poklapa s onima međunarodnih istraživanja (Dir i sur., 2013; Van Ouytsel i sur., 2014b). Traženje uzbuđenja je crta ličnosti koja motivira pojedince $\mathrm{k}$ upuštanju u različita rizična ponašanja $\mathrm{s}$ ciljem doživljavanja uzbuđujućeg iskustva (Zuckerman, 1979). Čini se da slanje seksualiziranih poruka zaista predstavlja uzbudljivu aktivnost adolescentima koji ne pridaju važnost mogućim negativnim posljedicama takvoga čina. Njihovo je podcjenjivanje negativnih ishoda vezanih uz visoko rizičnu i uzbudljivu aktivnost ono čime ova crta ličnosti predviđa, odnosno ima učinak na nečije ponašanje. Takva ponašanja često krše različite društvene norme i često se smatraju neprihvatljivima. Ponašajna ekspresija traženja uzbuđenja svakako ovisi i o društvenim normama. Arnett (1992) navodi da će rizična ponašanja biti rjeđa u restriktivnim društvima zbog društvenog ograničavanja različitih adolescentskih ponašanja. Upravo je karakteristika društvenog okruženja sudionika relativna nerestriktivnost koja omogućava navedenu ekspresiju.

Dir i Cyders (2014) također navode povezanost traženja uzbuđenja i slanja seksualiziranih poruka, ali samo kod djevojaka. Izostanak potvrde te povezanost i na poduzorku mladića autori su pripisali činjenici da su preko $70 \%$ uzorka činile djevojke. Rezultati istraživanja provedenog u više europskih zemalja također 
upućuju na povezanost traženja uzbuđenja i slanja seksualiziranih poruka (Baumgartner i sur., 2014).

Iako ne postoji konsenzus oko kategoriziranja slanja seksualiziranih poruka kao rizičnog ponašanja, rezultati dobiveni provedenim istraživanjem sugeriraju kako sklonost traženju uzbuđenja prethodi ovoj praksi, bar kad su u pitanju adolescenti u dobi između 16 i 17 godina. Kako većina sudionika nije bila spolno aktivna u vrijeme prikupljanja podataka, niti je navela kako šalje seksualizirane poruke, moguće je da traženje uzbuđenja vodi bržem otkrivanju vlastite seksualnosti ili motivira seksualno eksperimentiranje slanjem takvih poruka.

Rezultati su također pokazali kako su za djevojke korištenje SEM-a i seksualna inicijacija značajni pozitivni prediktori slanja seksualiziranih poruka. Ovi su rezultati donekle očekivani, no nije se očekivalo da će se pokazati samo za djevojke. Do sada je provedeno svega nekoliko istraživanja koja su kao rezultat utvrdila pozitivnu povezanost korištenja SEM-a i slanja seksualiziranih poruka (Tomić i sur., 2018; Van Ouytsel i sur., 2014a). S obzirom na rezultate dosadašnjih istraživanja koja sugeriraju povezanost korištenja SEM-a i različitih rizičnih seksualnih ponašanja (Peter i Valkenburg, 2016) te slanja seksualiziranih poruka i rizičnih seksualnih ponašanja (Kosenko i sur., 2017), nalaz je ovoga istraživanja o povezanosti ovih dvaju ponašanja očekivana.

Jedan je od mogućih razloga za ovakav rezultat različita varijabilnost uporabe SEM među djevojkama i mladićima. Značajno manji postotak djevojaka u odnosu na postotak mladića koristi SEM, a to je ponašanje vjerojatno izraženiji pokazatelj seksualiziranog ponašanja i/ili interesa za seksualnost kod djevojaka. Imajući u vidu da je društvena stigmatizacija seksualiziranog ponašanja snažnija u slučaju djevojaka (Lehmiller, 2014), moguće je da su djevojke koje se upuštaju u jednu vrstu seksualiziranog ponašanja (npr. korištenje SEM-a i stupanje u spolni odnos) "otpornije" na stigmatizaciju, odnosno više usmjerene na pozitivne aspekte vlastite seksualnosti, što rezultira i većom vjerojatnošću iskazivanja i drugih vidova seksualiziranoga ponašanja (npr. slanje seksualiziranih poruka). Čini se da djevojke koje su sudjelovale u ovom istraživanju imaju određene elemente dispozicijske osjetljivosti koja ih predisponira na takvo ponašanje. Moguća daljnja objašnjenja za ulogu SEM-a i seksualne inicijacije kod djevojaka u objašnjenju slanja seksualiziranih poruka možemo naći u teoriji seksualnih skripti (Gagnon i Simon, 1973) i 3 A-modelu (Wright, 2011). Seksualne se skripte odnose na kognitivne sheme koje predstavljaju internalizirane društvene poruke koja utječu na donošenje odluka, želje, očekivanja i ponašanja u seksualnim interakcijama, a ${ }_{3} \mathrm{~A}$-model navodi kako kroz usvajanje, aktivaciju i primjenu skripti mediji vrše svoj utjecaj. Drugim riječima, djevojke koje inicijalno koriste SEM usvajaju određene seksualne skripte, koje su većinom usmjerene na permisivna spolna ponašanja, što rezultira slanjem seksualiziranih poruka.

U literaturi se mogu naći različita objašnjenja povezanosti seksualne inicijacije i slanja seksualiziranih poruka. Primjerice, slanje seksualiziranih poruka može 
djelovati kao inicijator buduće seksualne aktivnosti. Razmjenjivanje seksualno sugestivnih poruka lako se može protumačiti kao poziv na spolni odnos. Moguće je i da se spolno aktivni pojedinci koriste slanjem seksualiziranih poruka kao metodom izražavanja vlastite seksualnosti (Temple i sur., 2012). Uzimajući u obzir da povezanost ne postoji na poduzorku mladića, moguće je da kod njih odnos seksualne inicijacije i slanja seksualiziranih poruka nije recipročan, bar u ovoj dobi, nego je slanje seksualiziranih poruka inicijator seksualne aktivnosti.

S obzirom na rezultate više različitih istraživanja očekivalo se kako će roditeljska kontrola, samopoštovanje, anksioznost i depresivnost te religioznost biti povezani sa slanjem seksualiziranih poruka (Dake i sur., 2012; Hall, Williams, Ford, Cromeans i Bergman, 2016; Tomić i sur., 2018; Van Ouytsel i sur., 2014b). Rezultati ovog istraživanja, međutim, nisu potvrdili ta očekivanja. Budući da je već navedeno da u ovom području istraživanja nalazi nisu konzistentni, postoje podaci i drugih istraživanja u kojima se te povezanosti nisu pokazale značajnima. Tako Hudson i Fetro (2015) nisu pronašli povezanost samopoštovanja i slanja seksualiziranih poruka. Moguće je objašnjenje da mladi visokog i niskog samopoštovanja podjednako često šalju takve poruke, ali zbog različitih razloga. Osobe visokog samopoštovanja mogu slati seksualizirane poruke svojim partnerima kao vrstu dara, dok osobe nižeg samopoštovanja to mogu raditi zbog partnerova pritiska. Buduća bi se istraživanja trebala usmjeriti na ispitivanje mogućih motiva koji se nalaze $u$ podlozi ovog ponašanja $s$ obzirom na razine samopoštovanja. Kod ispitivanja povezanosti anksioznosti i depresivnosti Temple i suradnici (2014) također nisu dobili povezanost ovih varijabli sa slanjem seksualiziranih poruka. Izostanak bi značajne povezanosti u našem uzorku mogao biti odraz relativno niskih razina anksioznosti i depresivnosti koje su adolescenti naveli, drugim riječima, male raširenosti negativnog afektiviteta. Imajući u vidu da su anksioznost i depresivnost ispitivane u kontekstu stanja kroz protekla dva tjedna, mala varijabilnost indikatora nije iznenađujuća. Buduća bi se istraživanja trebala usmjeriti i na ispitivanje uloge koju anksioznost i depresivnost kao crte ličnosti imaju u slanju seksualiziranih poruka.

Istraživanja povezanosti roditeljske kontrole, odnosno upućenosti roditelja u ono što njihova djeca čine te s kime i kako provode svoje slobodno vrijeme i slanja seksualiziranih poruka razmjerno su rijetka. Nešto su brojnija istraživanja koja su ispitivala roditeljsku kontrolu i korištenje mobilnih uređaja (Campbell i Park, 2014; Martinez-Prather i Vandiver, 2014). Prema nalazima, bez obzira na stupanj nadgledanja korištenja mobilnih uređaja od strane roditelja, adolescenti su podjednakom učestalošću slali seksualizirane poruke. Ovakvi rezultati nisu u skladu s očekivanjima s obzirom na to da se na hrvatskom uzorku pokazalo da postoji povezanost roditeljske kontrole i slanja seksualiziranih poruka (Tomić i sur., 2018). Moguće je da učinak roditeljske kontrole $\mathrm{s}$ vremenom slabi zbog toga što odrastanjem adolescenti postaju sve autonomniji i samostalniji. 
Nepostojanje povezanost između religioznosti i slanja seksualiziranih poruka nije očekivan nalaz. Ipak, moguće objašnjenje za njega valja potražiti i u činjenici da $\mathrm{u}$ ovakvim istraživanjima podaci o ulozi religioznosti nisu konzistentni. $\mathrm{S}$ jedne strane, u radu npr. Perkins i suradnika (2014), koji su ispitivali postoje li razlike u učestalosti slanja seksualiziranih poruka s obzirom na pohađanje religijskih obreda i razinu spiritualnosti, ta povezanost nije pronađena, dok Strassberg i suradnici (2014) navode negativnu povezanost religioznosti i slanja seksualiziranih poruka. Ipak, važno je naglasiti da se ovaj njihov nalaz pokazao samo za sudionike za koje je vjera u Boga bila iznimno važna. Kod umjereno religioznih sudionika nije zabilježena manja čestoća slanja seksualiziranih poruka. Riječju, rezultati upućuju na potrebu detaljnijeg ispitivanja specifičnih mehanizama veza između religioznosti i slanja seksualiziranih poruka.

U ovom se radu željelo utvrditi i postoji li povezanost tipa škole, postignutog stupnja obrazovanja roditelja te korištenja internetskih društvenih mreža sa slanjem seksualiziranih poruka. Do sada nisu provedena istraživanja koja su ispitivala ovu tematiku, a rezultati ovog rada sugeriraju kako te varijable nisu relevantne kada je $\mathrm{u}$ pitanju slanje seksualiziranih poruka kod adolescenata. Kako su postojala očekivanja da bi navedene varijable mogle imati ulogu u slanju seksualiziranih poruka kod adolescenata, u daljnjim bi istraživanjima bilo dobro provjeravati dobiveni nalaz.

$\mathrm{U}$ razmatranju rezultata provedenog istraživanja treba uzeti u obzir i određena ograničenja. Iako je u svakom mjerenju sudjelovalo otprilike 1200 sudionika, značajan broj sudionika ipak nije sudjelovao u oba mjerenja, što je bilo i očekivano. S obzirom na to da nisu svi adolescenti motivirani prisustvovati nastavi, a i moguća su izostajanja iz različitih objektivnih razloga, u svakom je mjerenju došlo do određenog osipanja sudionika koji na dan mjerenja nisu došli na nastavu, što je moglo rezultirati nešto pristranijim uzorkom. Nadalje, korištene su mjere samoprocjene koje sa sobom nose određene metodološke nedostatke, poput nemogućnosti provjere točnih odgovora i davanja socijalno poželjnih odgovora. Slanje je seksualiziranih poruka ispitivano isključivo kao aktivno ponašanje, a svakako bi bilo zanimljivo ispitati povezanost mjerenih varijabli s pasivnijim oblikom te prakse, tj. primanjem seksualiziranih poruka. Spolno je ponašanje mjereno jednim indikatorom koji se odnosio samo na spolni odnos, a moguće je da postoje razlike u ponašanju kada su u pitanju neki drugi oblici seksualnih aktivnosti (poput, na primjer, oralnog seksa), što bi se moglo ispitati u budućim istraživanjima. Iako je korišten veći broj prediktora, rezultati su pokazali kako cjelokupni model tumači manji dio dinamike slanja seksualiziranih poruka, što sugerira na postojanje relevantnih varijabli koje nisu bile obuhvaćene ovim radom, poput utjecaja vršnjaka ili statusa veze. Iako prema DSMM-u veliki broj varijabli može rezultirati nečijom sklonosti ka slanju seksualiziranih poruka, nalazi ovog rada sugeriraju kako ipak postoje neke druge varijable, kojima se ovaj rad nije bavio, a koje bi mogle bolje objasniti navedeno ponašanje. 
Usprkos navedenim nedostacima dobiveni rezultati pružaju smjernice za buduća istraživanja. Preporuka je da se dodatno ispita međuodnos traženja uzbuđenja kao inicijalnog prediktora s obzirom na seksualnu aktivnost sudionika. Korisno bi bilo ispitati i međuodnos seksualne inicijacije i slanja seksualiziranih poruka kod više uzastopnih mjerenja kod onih sudionika koji u prvom mjerenju nisu bili spolno aktivni, kako bi se utvrdilo koje ponašanje prethodi drugom. Općenito govoreći, osnovna je zadaća ovakvih istraživanja identifikacija varijabli važnih za razumijevanja dinamike slanja seksualiziranih poruka te uloge koju ono može imati za različite skupine. I konačno, na temelju se rezultata ovakvih istraživanja mogu kreirati programi i edukacije za mlade u čijem bi fokusu bilo odgovorno spolno ponašanje. Iz toga proizlazi i osnovna praktična primjena rezultata provedenog istraživanja. Znanstveni je doprinos ovoga rada daljnja provjera modela diferencijalne osjetljivosti na efekte medija (DSMM; Peter i Valkenburg, 2013), u cilju razumijevanja složenog ljudskog seksualnog ponašanja, s posebnim naglaskom razumijevanja seksualnog ponašanja adolescenata u kontekstu modernog doba i uporabe različitih vrsta medija i tehnologija u otkrivanju seksualnosti i seksualnog ponašanja. Ujedno se radi o jednom od prvih istraživanja u Republici Hrvatskoj koje se sustavno bavilo ispitivanjem ove tematike.

Prednosti su ovoga istraživanja poglavito longitudinalna analiza, koja $\mathrm{u}$ ispitivanje povezanosti uvodi temporalni slijed, te korišteni populacijski uzorak, koji povećava vanjsku valjanost dobivenih nalaza. Velika je pozornost bila posvećena $i$ proceduri prikupljanja podataka, odnosno zaštiti anonimnosti i povjerljivosti podataka, što smanjuje rizik društveno poželjnih odgovora.

Zaključno, prema rezultatima provedenoga longitudinalnog istraživanja mladići i djevojke skloniji traženju uzbuđenja pokazuju veću vjerojatnost slanja seksualiziranih poruka. Kod djevojaka se značajnim obilježjem pokazala i ranija razina uporabe SEM te seksualna inicijacija. Izneseni uvidi pridonose razumijevanju toga relativno novog virtualnog ponašanja, čija je popularnost, čini se, u porastu, te mogu poslužiti u izradi ili dopuni programa namijenjenih edukaciji adolescenata o seksualnom i reproduktivnom zdravlju (European Expert Group on Sexuality Education, 2015).

\section{Literatura}

Arnett, J. J. (1992). Reckless behavior in adolescence: A developmental perspective. Developmental Review, 12, 339-373.

Baumgartner, S. E., Sumter, S. R., Peter, J., Valkenburg, P. M. i Livingstone, S. (2014). Does country context matter? Investigating the predictors of teen sexting across Europe. Computers in Human Behavior, 34, 157-164.

Benotsch, E. G., Snipes, D. J., Martin, A. M. i Bull, S. S. (2013). Sexting, substance use, and sexual risk behavior in young adults. Journal of Adolescent Health, 52, 307-313. 
Bezinović, P., Marinović Bobinac, A. i Marinović Jerolimov, D. (2005). Kratka ljestvica religioznost: Validacija na uzorku adolescenata. Društvena istraživanja, 14, 135-153.

Braun-Courville, D. i Rojas, M. (2009). Exposure to sexually explicit web sites and adolescent sexual attitudes and behaviors. Journal of Adolescent Health, 45, 156-162.

Brown, J. D. i L'Engle, K. L. (2009). X-rated: Sexual attitudes and behaviors associated with U.S. early adolescents' exposure to sexually explicit media. Communication Research, 36, 129-151. doi:10.1177/0093650208326465

Campbell, S. W. i Park, Y. J. (2014). Predictors of mobile sexting among teens: Toward a new explanatory framework. Mobile Media \& Communication, 2, 20-39.

Cenat, J. M., Hebert, M., Blais, M., Lavoie, F., Guerrier, M. i Derivois, D. (2014). Cyberbullying, psychological distress and self-esteem among youth in Quebec schools. Journal of Affective Disorders, 169, 7-9.

Cooper, K., Quayle, E., Jonsson, L. i Svedin, G. C. (2016). Adolescents and self-taken sexual images: A review of literature. Computers in Human Behavior, 55, 706-716.

Crimmins, D. M. i Seigfried-Spellar, K. (2014). Peer attachment, sexual experiences, and risky online behaviors as predictors of sexting behaviors among undergraduate students. Computers in Human Behavior, 32, 268-275. https://doi.org/10.1016/j.chb.2013.12. 012 .

Cyders, M. A., Flory, K., Rainer, S. i Smith, G. T. (2009). The role of personality dispositions to risky behavior in predicting first-year college drinking. Addiction, 104, 193-202.

Dake, J. A., Price, J. H., Maziarz, L. i Ward, B. (2012). Prevalence and correlates of sexting behavior in adolescents. American Journal of Sexuality Education, 7, 1-15.

Delevi, R. i Weisskirch, R. S. (2013). Personality factors as predictors of sexting. Computers in Human Behavior, 29, 2589-2594.

Dir, A. L. i Cyders, M. A. (2014). Risks, risk factors, and outcomes associated with phone and internet sexting among university students in the United States. Archieves of Sexual Behavior, 44, 1675-1684. doi:10.1007/s10508-014-0370-7

Dir, A. L., Cyders, M. A. i Coskunpinar, A. (2013). From the bar to the bed via mobile phone: A first test of the role of problematic alcohol use, sexting, and impulsivity-related traits in sexual hookups. Computers in Human Behavior, 29, 1664-1670.

Doring, N. (2014). Consensual sexting among adolescents: Risk prevention through abstinence education or safer sexting? Cyberpsychology: Journal of Psychosocial Research on Cyberspace, 8, 1-18.

European Expert Group on Sexuality Education. (2015). Sexuality education - what is it? Sex Education, 16, 427-431. doi:10.1080/14681811.2015.1100599

Gagnon, J. H. i Simon, W. (1973). Sexual conduct: The social origins of human sexuality. Chicago: Aldine.

Gordon-Messer, D., Bauermeister, J., Grodzinski, A. i Zimmerman, M. (2013). Sexting among young adults. Journal of Adolescent Health, 52, 301-306. doi.org/10.1016/j. jadohealth.2012.05.013 
Gray, E. K. i Watson, D. (2001). Emotions, moods, and temperament: Similarities, differences, and a synthesis. U: R. Payne i G. Cooper (Ur.), Emotions at work (str. 2143). New York, NY: John Wiley \& Sons.

Hall, M., Williams, R. D., Ford, A. M., Murphy Cromeans, E. i Bergman, R. J. (2016). Hooking-up, religiosity, and sexting among college students. Journal of Religion and Health. doi:10.1007/s10943-016-0291-y

Harris, P. (1977). The effect of clustering on costs and sampling errors of random samples. Journal of the Market Research Society, 19, 112-122.

Hoyle, R. H., Fejfar, M. C. i Miller, J. D. (2000). Personality and sexual risk taking: A quantitative review. Journal of Personality, 68, 1203-1231.

Hudson, H. K. i Fetro, J. V. (2015). Sextual activity: Predictors of sexting behaviors and intentions to sext among selected undergraduate students. Computers in Human Behavior, 49, 615-622.

Jessor, R. i Jessor, S. (1977). Problem behavior and psychosocial development: A longitudinal study of youth. New York: Academic Press.

Klapper, J. T. (1960). The effects of mass communication. New York, NY: Free Press.

Klettke, B., Hallford, D. J. i Mellor, D. J. (2014). Sexting prevalence and correlates: A systematic literature review. Clinical Psychology Review, 34, 44-53.

Kosenko, K., Luurs, G. i Binder, A. R. (2017). Sexting and sexual behavior, 2011-2015: A critical review and meta-analysis of growing literature. Journal of Computer-Mediated Communication, 22, 141-160. doi:10.1111/jcc4.12187

Kroenke, K., Spitzer, R. L., Williams, J. B. W. i Lowe, B. (2009). An ultra-brief screening scale for anxiety and depression: The PHQ-4. Psychosomatics, 50, 613-621.

Kroenke, K., Spitzer, R. L., Williams, J. B. W., Monahan, P. O. i Lowe, B. (2007). Anxiety disorders in primary care: Prevalence, impairment, comorbidity, and detection. Annals of Internal Medicine, 146, 317-325.

Lamers, F., van Oppen, P., Comijs, H. C., Smit, J. H., Spinhoven, P., van Balkom, A. J. L. M., ... Penninx, B. W. (2011). Comorbidity patterns of anxiety and depressive disorders in a large cohort study: The Netherlands study of depression and anxiety (NESDA). Journal of Clinical Psychiatry, 72, 341-348.

Landripet, I., Baćak, V. i Štulhofer, A. (2011). Changes in HIV and STI related sexual risk taking among young Croatian adults: Findings from the 2005 and 2010 populationbased surveys. Croatian Medical Journal, 52, 458-468.

Lehmiller, J. J. (2014). The psychology of human sexuality. New York: Wiley Blackwell.

Lejuez, C. W., Simmons, B. L., Aklin, W. M., Daughters, S. B. i Dvir, S. (2004). Risk-taking propensity and risky sexual behavior of individuals in residential substance use treatment. Addictive Behaviors, 29, 1643-1647.

Lenhart, A. (2009). Overview: Teens and sexting: How and why minor teens are sending sexually suggestive nude or nearly nude images via text messaging. Pew Internet and American Life Project. Preuzeto s http://www.pewinternet.org/ /media//Files/Reports/ 2009/PIP_Teens_and_Sexting.pdf 
Leshnoff, J. (2009). $C^{*} U^{*} 2$ night: Sexting not just for kids. AARP Magazine. Preuzeto s http://www.aarp.org/relationships/love-sex/info-11-2009/sexting_not_just_for_kids.html

Magnani, R. J., Seiber, E. E., Gutierrex, E. Z. i Vereau, D. (2001). Correlates of sexual activity and condom use among secondary school students in urban Peru. Studies in Family Planning, 32, 53-66.

Martinez-Prather, K. i Vandiver, D. M. (2014). Sexting among teenagers in the United States: A retrospective analysis of identifying motivating factors, potential targets, and the role of a capable guardian. International Journal of Cyber Criminology, 8, 21-35.

McDonald, D. G. (2009). Media use and the social environment. U: R. L. Nabi i M. B. Oliver (Ur.), Media processes and effects (str. 251-268). Los Angeles, CA: Sage.

Mitchell, K. J., Finkerhor, D., Jones, L. M. i Wolak, J. (2012). Prevalence and characteristics of youth sexting: A national study. Pediatrics, 129, 13-20.

Ostrager, B. (2010). SMS. OMG! LOL! TTYL: Translating the law to accommodate today's teens and the evolution from texting to sexting. Family Court Review, 48, 712-726. doi.org/10.1111/j.1744-1617.2010.01345.x

Perkins, A. B., Becker, J. V., Tehee, M. i Mackelprang, E. (2014). Sexting behaviors among college students: Cause for concern? International Journal of Sexual Health, 26, 79-92.

Peter, J. i Valkenburg, P. M. (2016). Adolescents and pornography: A review of 20 years of research. The Journal of Sex Research, 53, 509-531. doi:0.1080/00224499.2016. 1143441

Rice, E., Rhoades, H., Winetrobe, H., Sanchez, M., Montoya, J., Plant, A. i Kordic, T. (2012). Sexually explicit cell phone messaging associated with sexual risk among adolescents. Pediatrics, 130, 667-673.

Rosenberg, M. (1965). Society and the adolescent self-image. Princeton, NJ: Princeton University Press.

Scholes-Balog, K., Francke, N. i Hemphill, S. (2016). Relationships between sexting, selfesteem, and sensation seeking among Australian young adults. Sexualization, Media \& Society, 2, 1-8. doi:10.1177/2374623815627790

Simons, L. G., Burt, C. H. i Peterson, F. R. (2009). The effect of religion on risky sexual behavior among college students. Deviant Behavior, 30, 467-485.

Spriggs, A. i Halpern, C. (2008). Sexual debut timing and depressive symptoms in emerging adulthood. Journal of Youth and Adolescence, 37, 1085-1096.

Stephenson, M. T., Hoyle, R. H., Palmgreen, P. i Slater, M. D. (2003). Brief measures of sensation seeking for screening and large-scale surveys. Drug and Alcohol Dependence, 72, 279-286.

Strasburger, V. C., Donnerstein, E. i Bushman, B. J. (2014). Why is it so hard to believe that media influence children and adolescents? Pediatrics, 133, 571-573.

Strassberg, D. S., Rullo, J. E. i Mackaronis, J. E. (2014). The sending and receiving of sexually explicit cell phone photos ("Sexting") while in high school: One college's students' retrospective reports. Computers in Human Behavior, 41, 177-183. 
Štulhofer, A., Šoh, D., Jelaska, N., Baćak, V. i Landriper, I. (2011). Religiosity and sexual risk behavior among Croatian college students, 1998-2008. Journal of Sex Research, 48, 360-371.

Temple, J. R. i Choi, H. (2014). Longitudinal association between teen sexting and sexual behavior. Pediatrics, 134, 1287-1292. doi:10.1542/peds.2014-1974

Temple, J. R., Le, V. D., van den Berg, P., Ling, Y., Paul, J. A. i Temple, B. W. (2014). Brief report: Teen sexting and psychosocial health. Journal of Adolescence, 37, 33-36.

Temple, J. R., Paul, J. A., van den Berg, P., Le, V. D., McElhany, A. i Temple, B. W. (2012). Teen sexting and its associations with sexual behaviours. Archives of Pediatrics and Adolescent Medicine, 166, 828-833.

The National Campaign. (2008). Sex and tech: Results from a survey of teens and young adults. (Online). The National Campaign to Prevent Teen and Unplanned Pregnancy. Preuzeto s http://www.ncdsv.org/images/natlcampprevteenpreg_sextech_summary.pdf

Tomić, I., Burić, J. i Štulhofer, A. (2018). Associations between adolescent use of sexually explicit material and sexual behavior: Does parental monitoring play a role? Archives of Sexual Behavior, 47, 1881-1893. doi:10.1007/s10508-017-1097-z

Træen, B., Štulhofer, A. i Landripet, I. (2011). Young and sexual in Norway and Croatia: Revisiting the Scandinavian versus Mediterranean gendered pattern of sexual initiation. International Journal of Sexual Health, 23(3), 196-209.

Valkenburg, P. M. i Cantor, J. (2000). Children's likes and dislikes in entertainment programs. U: D. Zillmann i P. Vorderer (Ur.), Media entertainment: The psychology of its appeal (str. 135-152). Mahwah, NJ: Erlbaum.

Valkenburg, P. M. i Peter, J. (2013). The differential susceptibility to media effects model. Journal of Communication, 63, 221-243. doi:10.1111/jcom.12024

Vanden Abeele, M., Campbell, S. W., Eggermont, S. i Roe, K. (2014). Sexting, mobile porn use, and peer group dynamics: Boys' and girls' self-perceived popularity, need for popularity, and perceived peer pressure. Media Psychology, 17, 6-33.

Van Ouytsel, J., Ponnet, K. i Walrave, M. (2014a). The associations between adolescents' consumption of pornography and music videos and their sexting behavior. Cyberpsychology, Behavior and Social Networking, 17, 772-778. doi:10.1089/cyber. 2014.0365

Van Ouytsel, J., Van Gool, E. i Ponnet, K. (2014b). Brief report: The association between adolescents' characteristics and engagement in sexting. Journal of Adolescence, 37, 1387-1391.

Van Ouytsel, J., Walrave, M., Ponnet, K. i Van Gool, E. (2014c). Sexting: Between thrill and fear-how schools can respond. The clearing house. A Journal of Educational Strategies, Issues and Ideas, 87, 204-212.

Vrselja, I., Pacadi, D. i Maričić, J. (2015). Odnos sekstinga sa seksualno rizičnim ponašanjem i nekim psihosocijalnim čimbenicima. Psihologijske teme, 24, 425-447. 
Wang, B., Stanton, B., Deveaux, L., Li, Y. i Lunn, S. (2015). Dynamic relationships between parental monitoring, peer risk involvement and sexual risk behavior among Bahamian mid-adolescents. International Perspectives on Sexual and Reproductive Health, 41, 8998.

Wight, D., Williamson, L. i Henderson, M. (2006). Parental influences on young people's sexual behavior: A longitudinal analysis. Journal of Adolescence, 29, 473-494.

Wingood, G. M., DiClemente, R. J., Harrington, K., Davies, S., Hook, E. W. i Oh, M. K. (2001). Exposure to X-rated movies and adolescent's sexual and contraceptive-related attitudes and behaviors. Pediatrics, 107, 1116-1119.

Wright, P. J. (2011). Mass media effects on youth sexual behavior. Communication Yearbook, 35, 343-386.

Zuckerman, M. (1979). Sensation seeking: Beyond the optimal level of arousal. Hillsdale, NJ: Lawrence Erlbaum Associates.

Zuckerman, M. (1991). Sensation seeking: The balance between risk and reward. U: L. P. Lipsitt i L. L. Mitnick (Ur.), Self regulatory behavior and risk taking: Causes and consequences (str. 143-152). Norwood, NJ: Ablex Publishing Corporation.

Zuckerman, M. (1994). Behavioral expressions and biosocial bases of sensation seeking. New York, NY, US: Cambridge University Press.

\title{
The Role of Socialization, Dispositional and Behavioral Variables in the Dynamics of Sexting among Adolescents
}

\begin{abstract}
The research suggests that a significant number of adolescents is using sexually explicit material (SEM). Simultaneously, the rapid development of mobile technologies and online social networks led to a new type of sexualized behaviour - sexting. Current research pointed to the relationship between SEM use, sexting, and risky sexual behaviour. Considering Differential Susceptibility to Media Effects Model (DSMM; Peter \& Valkenburg, 2013), the aim of this longitudinal research was to assess the contribution of type of high school, parental education, parental monitoring, sensation seeking, self-esteem, anxiety and depression, religiosity, sexual initiation, SEM use, and online social network use in explaining sexting among adolescents. The research was conducted on a population sample of 791 high school students in Rijeka (302 boys and 489 girls) with a mean age of 15.8 years $(S D=0.51)$. The data were collected at two time points with 12 months difference. Out of a total number of respondents, $46 \%$ boys in first and $37.7 \%$ in the second wave reported sexting at least once, while $36.6 \%$ of girls in first and $33.7 \%$ in second wave reported the sexting at least once. Considering the differences in adolescents' sexual socialization, all analyses were done separately for boys and girls. The results of the multivariate analysis (we used hierarchical regression analysis while controlling the outcome initial values) revealed that girls higher on sensation seeking, sexually active girls, and the ones using SEM more often at wave 1 were more likely to sext in wave 2. In a sample of boys, only sensation seeking emerged as a positive predictor of sexting at wave 2 . Considering the enormous popularity of online networks, these results point to the importance of media literacy education as well to better understanding the characteristics of adolescents engaging in sexting.
\end{abstract}

Keywords: sexually explicit material, sexting, sensation seeking, sexual initiation, adolescents 


\title{
El papel de factores disposicionales, conductuales y de socialización en la dinámica de enviar los mensajes sexualmente explícitos en adolescencia
}

\begin{abstract}
Resumen
Las investigaciones sugieren que un número significativo de jóvenes usa el material sexualmente explícito (MSE). Al mismo tiempo, el desarrollo de tecnologías móviles y redes sociales han posibilitado una nueva conducta sexual - el envío de mensajes sexualizados (inglés: sexting). Las investigaciones previas relacionaron el uso de MSE con conductas sexuales de riesgo y con algunas otras consecuencias no deseadas. Basándose en el Modelo de Sensibilidad Diferencial ante los Efectos de Medios de Comunicación (Peter y Valkenburg, 2013), el objetivo de esta investigación longitudinal fue evaluar la contribución que tienen el grado de formación de los padres, control parental, autoestima, búsqueda de excitación, ansiedad y depresión, religiosidad, iniciación sexual, uso de redes sociales y uso de MSE para predecir el envío de mensajes sexualmente explícitos. La investigación se llevó a cabo en la muestra de 791 alumnos de secundaria de Rijeka (308 chicos y 489 chicas) de la edad promedio de $15.8(s=0.51)$. Los datos se recolectaron en dos periodos con 12 meses de diferencia. Del número total de participantes, el $46 \%$ de los chicos en la primera y el $37.7 \%$ en la segunda medición al menos una vez enviaron un mensaje sexualizado, mientas que lo mismo hicieron el $36.6 \%$ de las chicas en la primera y el 33.7\% en la segunda medición. Dado que la socialización sexual de adolescentes sigue siendo específica por género, los análisis se llevaron a cabo separadamente (chicos y chicas). Los resultados del análisis multivariante (se utilizó la regresión jerárquica logística con el control de nivel inicial de resultados) demostró que las chicas que en la primera medición mostraban tendencia hacia la búsqueda de excitación, las que ya habían tenido la relación sexual y aquellas que usaban MSE, en el segundo punto de medición mandaban mensajes sexuales explícitos con más frecuencia. En la submuestra de chicos, sólo la búsqueda de excitación fue predictor positivo significativo. Teniendo en cuenta la popularidad enorme que las redes sociales tienen entre los jóvenes, los resultados obtenidos indican la importancia de promover sistemáticamente la alfabetización mediática y el mejor entendimiento de motivación para enviar mensajes sexualizados en adolescencia, tanto como los posibles riesgos.
\end{abstract}

Palabras clave: material sexual explícito, mensajes sexualizados, búsqueda de excitación, iniciación sexual, adolescentes

Primljeno: 28.08.2017. 